\title{
Bacterial and heavy metal contamination in selected commonly sold herbal medicine in Blantyre, Malawi
}

\author{
Martin Henderson Kalumbi ${ }^{1}$, Martin Charles Likongwe ${ }^{2}$, John Mponda ${ }^{3}$, Bhahat Lawlley Zimba ${ }^{4}$, \\ Odala Phiri ${ }^{1}$, Trancizeo Lipenga ${ }^{5}$, Timothy Mguntha ${ }^{2}$, Joseph Kumphanda ${ }^{4}$ \\ 1. Malawi Adventist University, Malamulo College of Health Sciences Campus, Biomedical Science Department, Microbiology Research Group. \\ 2. University of Malawi, Chancellor College, Zomba, Malawi. \\ 3. University of Ibadan, Faculty of Pharmacy, Nigeria. Africa Centre of Excellence in Public Health and Herbal Medicine, University of Malawi. \\ Department of Pharmacy, College of Medicine, University of Malawi, Malawi. \\ 4. Malawi University of Science and Technology, Malawi. \\ 5. University of Malawi, College of Medicine.
}

Correspondence; Malawi Adventist University, Malamulo College of Health Sciences Campus, P.O Box 55, Makwasa, Thyolo, Malawi. Email: martinkalumbi@yahoo.com or kalumbim@mchs.adventist.org:Cell: 0881130704

\section{Background}

\section{Abstract}

There has been an increase in use of herbal medicine worldwide. It is either used as a stand-alone or complementary therapy to conventional medicine due to past good experience, poverty and family traditions. In Malawi, there are no regulations governing the supply, acquisition, marketing and quality enforcement of herbal medicine. This compromises its safety thereby exposing consumers to avoidable bacteria and heavy metals leading to various adverse health effects.

Methods

Cross-sectional laboratory experiments were conducted to determine bacterial and heavy metal contamination of herbal medicine commonly sold in Blantyre, Malawi. A total of 47 samples which were in three formulations namely liquid, powder and tablet were used in the experiments. 29 samples were used for bacterial limit tests and 18 samples were used for heavy metal analysis. Bacterial contamination was determined by streak plate method and biochemical tests while heavy metals were determined by atomic absorption spectroscopy. Descriptive statistics and t-tests were calculated using Microsoft excel and SPSS software programs.

Results

Twenty out of the 29 samples (68.9\%) were contaminated with Bacillus, coagulase negative Staphylococcus, Klebsiella, Enterobacter, Citrobacter and other-Coliform bacterial species. Most isolated microorganism was Citrobacter spp. (30\%), followed by Bacillus spp. (25\%). Out of 20 contaminated samples, $75 \%$ were contaminated with coliforms. From these 75\% which were contaminated with coliforms, $93.3 \%$ of them exceeded WHO regulatory limit (103 CFU/g for enterobacteria). Although liquid samples had the highest level of bacterial contaminants, the count was not statistically different from other formulations $(\mathrm{P}=0.058)$. For heavy metals, lead and cadmium were detected and $67 \%$ of the samples had lead levels exceeding regulatory limits.

Conclusion

Levels of bacterial and lead contamination in herbal medicine from Blantyre markets are far above acceptable limits set by WHO and Canadian guidelines. The use of these herbal medicines is a major risk to the health of consumers.

Key Words

Herbal medicine, Blantyre markets, Bacteria, Heavy metal, Contamination, WHO guidelines

\section{Introduction}

The use of herbal medicine has increased globally due to people's dissatisfaction with conventional medicine, past good experience, poverty and family traditions ${ }^{1-3}$. It is an undeniable fact that traditional medicine plays a vital role in global health and marketing, although it raises interesting safety questions ${ }^{1,3,4}$. For instance, in developing countries like Malawi there are no regulations that apply to the manufacturing of herbal medicines and there are currently no safety requirements ${ }^{1}$. Lack of mechanisms to monitor contaminants of herbal medicine such as bacteria and chemicals and assessment of good professional practices from providers side, might be adverse health risk factors to users of herbal medicines ${ }^{1}$.

Indeed, bacteria are increasingly threatening safety of food and herbal medicine and are among the leading causes of morbidity and mortality in low and middle-income countries $^{5-7}$. Plant materials are usually contaminated with aerobic and enterobacteria which are the major causes of gastroenteritis, diarrhoea and food poisoning ${ }^{4,8-10}$. These pathogens are indigenous to the soil hence the contamination of the herbs is attributable to growing, harvesting and post harvesting practices ${ }^{11-13}$. Sometimes herbs are heavily contaminated during marketing as a result of poor hygiene $e^{4}$ 14, 15. The total number of microorganisms in a medicinal plant is influenced by the antibacterial properties of the plant, distance of the plant from the soil and the ratio between the size of the plant surface and the sample weight of the herbs and climate ${ }^{4}$. Antibiotic resistant strains of Bacillus spp., Erwinia spp., Ewingella americana, Staphylococcus spp. and Enterobacter cloacae have been isolated from various medicinal plants which are some of the sources of infections ${ }^{16}$. This resistance is due to the presence of antibacterial properties which forces microorganisms to mutate and render resistance to antibiotics with similar chemical structures as a result of misuse of herbs ${ }^{17-19}$. Infectious diseases caused by antimicrobial-resistant microbes (ARM) have been frequently reported for decades ${ }^{20,21}$.

In addition to bacterial contamination, the presence of heavy metal contaminants in herbal medicine and food has become 
a public health concern as non-communicable diseases continue to threaten human health globally ${ }^{22}$. The World Health Organization (WHO) has set guidelines for tolerable human exposures for some important foreign matter, metals, organic, microbial toxins and radioactive pollutants in herbal materials ${ }^{23}$. Medicinal plants are commonly contaminated with metals when they are grown in areas of mining, roadsides, smelting pollution, anthropogenic processes (i.e. application of organic manures, synthetic fertilizers, lime and unhygienic storage conditions) ${ }^{24-29}$. Several reports have also indicated that herbal medicines are largely contaminated by human beings through deliberate addition of heavy metals due to their perceived medicinal properties ${ }^{30-34}$. Most of these contaminants can be minimized if sufficient attention is given to good agricultural practices, preparation, collection, packaging, quality assurance and control of herbal medicines ${ }^{35,} 36$. These practices do not only impact on herbal safety and efficacy but also consumer safety and international trade. Heavy metal contamination of herbal medicine has caused serious health risks to human beings even at a very low concentration than previously anticipated. Among others several cases of human diseases, cancers, cellular damage, malfunction and malformation of organs have been reported ${ }^{37-41}$. It is estimated that over $80 \%$ of African population depend on herbal medicine ${ }^{42,43}$ yet there is no safety regulations that govern their use. Until now, there is no published report on bacteriological and heavy metal contamination of Malawian herbal medicine. In this sense, the present study was therefore carried out to determine bacterial and heavy metal contamination of the commonly used local herbal medicine in Blantyre, Malawi.

\section{Materials and Methods}

\section{Study design}

The study employed an experimental based design. This involved laboratory analysis of bacteria and heavy metals of collected herbal medicine.

\section{Preliminary ethnobotanical study, sample selection and collection}

Preliminary ethnobotanical exploration was carried out among 8 herbal sellers and 2 herbalists after giving their oral informed consent. This initial study determined which herbal products were commercially available and popularly used in Blantyre, Malawi (Figure 1). Eight species of herbal medicines which were traditionally used for body detoxification and cleaning, treatment of constipation, gastrointestinal tract detoxification, manhood power enhancement, treating abdominal pain, and diarrhoea, were collected. The formulations were identified in local language (Nyanja) and were reported as nchape (detoxifier), oletsa kudzimbidwa (for constipation), ochapam'mimba (laxative), mphamvu za abambo kuchipinda (libido booster), kuletsa kupweteka kwa m'mimba (for abdominal pain) and kutsekamimba (for diarrhoea). Before herbal medicinal sample collection, oral consent was obtained using a standardized form of asking questions to all the vendors. A total of 47 various herbal medicinal formulations were collected at random in April 2019 from randomly selected herbal markets in Blantyre, Malawi. A total of 29 samples were used for determination of bacterial contamination and 18 samples were used for determination of heavy metal content. Selection of 18 samples for heavy metal analysis was based on the physical similarities of the samples, representation of the sampling sites and the cost of laboratory analysis. Three formulations of herbal medicines were collected namely liquid $(\mathrm{L})$, powder $(\mathrm{P})$ and tablet $(\mathrm{T})$. Eight (8) bottles of liquid, twelve (12) packets of powder and

\section{BLANTYRE CITY}

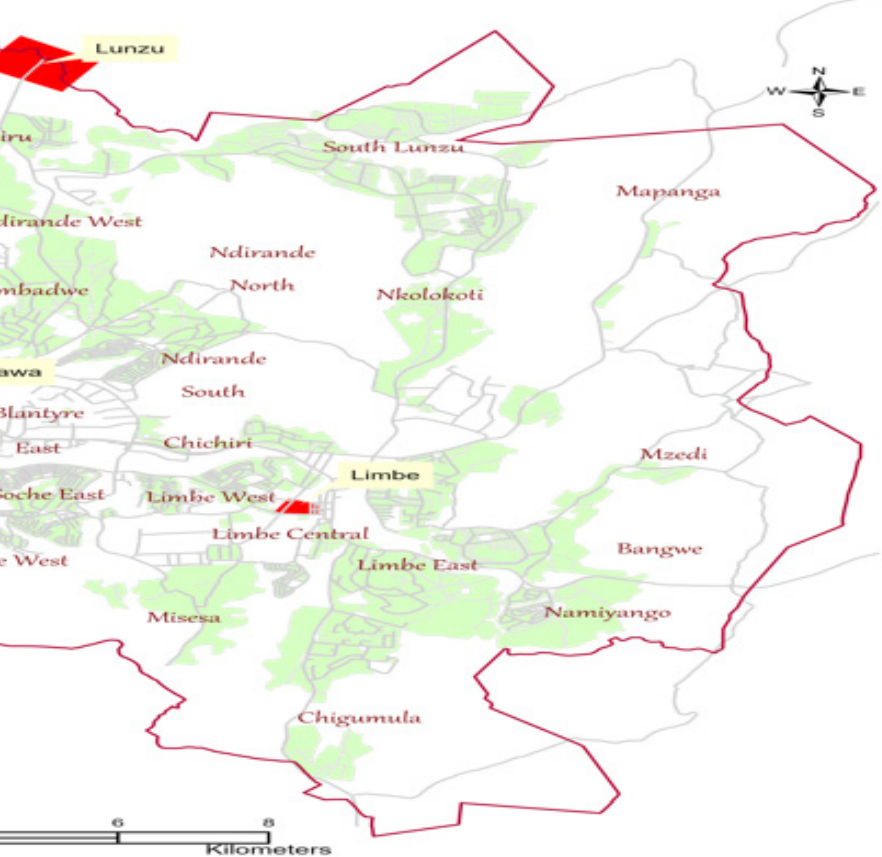

Figure 1. Map of Blantyre city indicating study sites

nine (9) packets of tablets formulations of herbal medicinal samples were collected giving a total of 29 samples for bacterial analysis. Six samples from each formulation were used for heavy metal determination. The herbal medicines were collected aseptically and packaged in clean containers and transparent polyethylene bags. Then after, the samples were transported to Malawi Adventist University, Malamulo College of Health Sciences Campus and Malamulo Hospital Microbiology Laboratory for bacterial contamination analysis. Heavy metal contamination analysis was carried at University of Malawi, Chancellor College Chemistry laboratory. All the samples were coded and analyses were done in duplicates for microbiological $\left(\mathrm{WHO}^{23}\right)$ and triplicates for heavy metal samples.

\section{Identification and quantification of bacterial isolates}

Upon arrival in the laboratory, bacteriological contaminants were determined according to $\mathrm{WHO}^{23}$ and National Committee for Clinical Laboratory Standards (NCCLS) ${ }^{44}$ guidelines. All aseptic and quality assurance requirements were followed accordingly during bacteriological analysis of herbal medicine. One gram (g) of each herbal product was 
Table 1. Frequency of bacterial contaminants from herbal medicinal samples $(\mathbf{n}=20)$

\begin{tabular}{|l|l|l|}
\hline Bacterial isolate & $\begin{array}{l}\text { Number of } \\
\text { contaminated } \\
\text { samples } \\
\text { (percentage) }\end{array}$ & $\begin{array}{l}\text { Gram stain } r \\
\text { eaction }\end{array}$ \\
\hline Bacillus spp. & $5(25 \%)$ & Gram positive \\
Citrobacter spp. & $6(30 \%)$ & Gram negative \\
Co.N. Staphylococcus spp. & $1(15 \%)$ & Gram positive \\
Enterobacter spp. & $3(15 \%)$ & Gram negative \\
Klebsiella spp. & $2(10 \%)$ & Gram negative \\
Other-coliform & $3(15 \%)$ & Gram negative \\
& & \\
& & \\
& & \\
\hline
\end{tabular}

n: sample size, spp.: species, Co. N: coagulase negative

suspended in 1 millilitres $(\mathrm{ml})$ of sterile room temperature distilled water. Then after, the contents were mixed thoroughly using a vortex mixer (IKA, Vortex Genius 3, UK) and sieved aseptically. Serial dilution was performed and then $0.1 \mathrm{ml}$ of the contents were transferred and inoculated into a sterile culture media in a petri dish using streak plate method. The tests were performed in duplicates and expressed as a mean of duplicate samples. The media used for bacterial determination were plate count agar, Mannitol salt agar, Salmonella-Shigella agar, MacConkey agar and nutrient agar (Scharlau, Germany). The plates were incubated at $37^{\circ} \mathrm{C}$ for 12-18 hours. After incubation, presence of distinct colonies on the media was regarded as positive and colony forming units were determined. Bacterial isolates on each culture were gram stained and following the results, isolates were then biochemically identified.

\section{Determination of heavy metal levels}

Determination of lead, mercury, arsenic and cadmium levels in herbal medicinal samples was done according to $\mathrm{WHO}^{23}$ and Obi et al. ${ }^{45}$ with slight modifications. Sample preparation for elemental analysis involved accurately weighed, finely cut and homogeneously mixed solid samples in a cleaned silica crucible for wet oxidation digestion in order to release the elements. Heavy metal free $\mathrm{HNO}_{3}-\mathrm{HClO}_{4}$ di-acid mixture was used for wet oxidation digestion. Then after exactly 1 $g$ of the sample was weighed on an analytical balance and $3 \mathrm{ml}$ of nitric acid was added to the sample. The mixture was then placed in a $250 \mathrm{ml}$ conical flask on a hot plate for 1 hour at $145^{\circ} \mathrm{C}$. After that, $4 \mathrm{ml}$ of di-acid mixture (HNO3 and $\mathrm{HClO} 4$ ) was added and the mixture was left on the hot plate for another hour with adjusted temperature of $240^{\circ} \mathrm{C}$ until the brown fumes cleared. The sample was left to cool. The digestion mixture was filtered into 100 ml Calibrated volumetric flask using Whatman no 1 filter paper and diluted up to the mark with double-distilled water. The filtrate was used for determination of heavy metals by Atomic absorption spectrometry (AAS), AA240FS Model by Agilent Technologies, Australia. The Standard solutions were prepared and every sample was tested in parallel with a blank. All the aforementioned chemicals were of analytical grade and purchased from Sigma, UK.

\section{Data analysis}

Data analysis was done using Microsoft excel (Microsoft office professional plus 2013) and Statistical Package for the Social Sciences (SPSS) version 22 (SPSS Inc. Chicago,
IL, USA) at 0.05 significance level. Descriptive statistics and t-tests were calculated.

\section{Results \\ Level of bacterial contamination}

Results of bacterial contamination of herbal medicine are presented in Table 1 . Irrespective of the herbal medicinal formulation, $68.9 \%(\mathrm{n}=20)$ of the samples were contaminated with pathogenic bacteria of which $75 \%$ were contaminated with coliforms. The most prevalent bacteria isolated from the samples were Citrobacter spp. while Coagulase negative Staphylococcus spp. were the least common bacteria recovered (Table 1).

Table 2. Levels of heavy metals in selected herbal medicine ( $n=18)$

\begin{tabular}{|l|l|l|}
\hline $\begin{array}{l}\text { Type of } \\
\text { Heavy metal }\end{array}$ & $\begin{array}{l}\text { Amount in } \\
\text { samples (mg/g) } \\
\text { (mean } \pm \text { SD) }\end{array}$ & $\begin{array}{l}\text { Percentage of samples } \\
\text { exceeding } \\
\text { acceptable limits }\end{array}$ \\
\hline Lead & $0.091 \pm 0.107$ & $67 \%$ \\
\hline Mercury & $<0.001$ (undetectable) & $0 \%$ \\
\hline Cadmium & $0.0026 \pm 0.0018$ & $11 \%$ \\
\hline Arsenic & $<0.045$ (undetectable) & $0 \%$ \\
\hline & $\begin{array}{l}\text { Lead, Mercury, Arsenic and Cadmium detection limits were } \\
<0.001,0.001,0.045 \text { and } 0.0014 \text { respectively. }\end{array}$
\end{tabular}

The pattern of bacterial contamination in herbal medicine for all the formulations is summarized in Figure 2. It was observed that a single sample was able to have different types of microorganisms as shown in Figure 2 where both Enterobacter and Bacillus spp. were detected in Lunzu powder sample 1. Out of the total coliform contaminated samples, $93.3 \%$ (14 out of 15 ) exceeded WHO regulatory limit of $10^{3}$ colony forming unit (CFU)/g (for enterobacteria) for medicinal plant materials intended for internal use ${ }^{23}$, with a mean count of $1506.7 \mathrm{CFU} / \mathrm{ml}$. In contrast, total colony forming units of aerobic organism were within WHO acceptable regulatory limits $\left(10^{5} \mathrm{CFU} / \mathrm{g}\right.$ for aerobic bacteria) with mean count of $1283.3 \mathrm{CFU} / \mathrm{ml}$. However, there was no significant variation $(P=0.051)$ in mean colony forming units between coliforms and aerobic bacteria. Citrobacter spp. was the most frequently detected organism and had highest number of colony forming units of 2500 per $\mathrm{ml}$ in one of the Limbe liquid samples while Klebsiella spp. had the least number of 400 detected in Lunzu tablet sample. Bacillus spp., Co.N. Staphylococcus spp. and Klebsiella spp. were among the least isolated bacteria. However, it was noted that they had similar occurrence pattern and they were the only genera which were detected in tablet samples. There was no obvious pattern of bacterial contamination occurrence with exception for Enterobacter spp. whose occurrence was only observed among powder formulations. It is worth noting that overall, Bacillus spp. was not only the second most detected species but also the only species which was detected almost in all the three sample formulations. It is also worth to note that the total bacterial count was not statistically different among the three formulations $(p=0.058)$.

The levels of bacterial contamination in herbal products samples obtained from Limbe, Mibawa and Lunzu markets of Blanyre City in Malawi are summarized in Figure 3. Liquid formulated samples had the highest level of bacterial 
Level of bacterial contamination in individual samples

$$
\text { (cfu/ml) }
$$

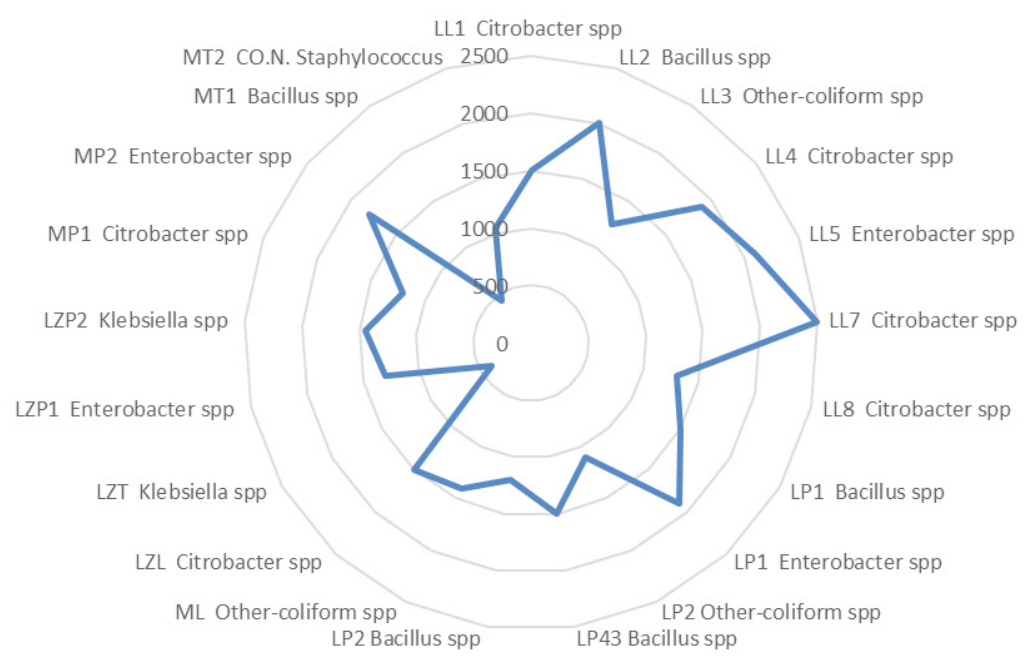

Figure 2. Pattern of bacterial contamination in herbal medicine. LL1 Limbe liquid 1, LL2 Limbe liquid 2, LL3 Limbe liquid 3, LL4 Limbe liquid 4, LL5 Limbe liquid 5, $M L$ Mibawa liquid, $L Z L$ Lunzu liquid, LZP Lunzu Powder, LZT Lunzu Tablet, LP1 Lunzu powder1, LZP2 Lunzu powder 2, LP1 Limbe powder 1, LP2 Limbe powder 2, MP1 Mibawa powder 1, MP2 Mibawa powder 2. LP4 Limbe powder 4, LP5 Limbe powder 5, LP3 Limbe powder 3, LT1 Limbe tablet 1, MT Mibawa tablet.

\section{Mean cfu/ml}

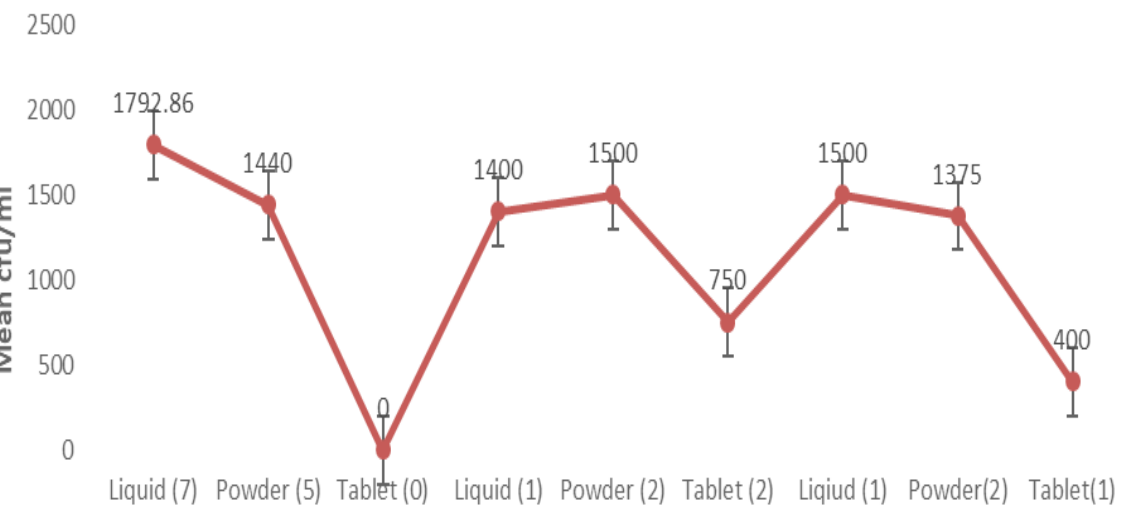

$-500$

$$
\text { Limbe }
$$

$\mathrm{Mg} / \mathrm{g}$. Contamination levels were compared to Canadian regulatory limits [23] and $67 \%(\mathrm{n}=18)$ of the samples had lead levels exceeding the limits while $11 \%$ of the samples had cadmium levels exceeding the aforementioned limits [23]. The highest concentrations of metal contamination were observed in liquid samples. Of the four metals, only mercury and arsenic were below detection levels.

\section{Discussion}

The present experiment was conducted to determine bacterial and heavy metal contamination of herbal medicine. The data from the present study makes it clear that bacterial contamination in herbal medicine is persistent in Malawi. In our study, coliform bacteria were commonly isolated organisms with Citrobacter spp. as the common contaminant which indicates poor sanitation ${ }^{47}$. The prevailing risk of bacterial contamination of herbs could be attributed to poor agronomic, preparation and packaging practices ${ }^{11-15}$. Moreover, there is no national guidelines and efficient safety systems on the use of herbal medicine in most of the developing settings. This is an indication that measures set by the WHO through its guidelines are not being implemented by the regulatory authorities such as Pharmacy Medicines Regulatory Authority and the Malawi Bureau of Standards. This may have resulted in trade of herbal medicines that are not safe for consumption.

Bacillus spp. were the only gram positive bacteria which were isolated in most of the herbal medicinal samples. The presence Bacillus spp. could be due to its ability to form spores given unconducive environment, as such they can exist in the environment for a long time. Unfortunately, consumption of contaminated food with preformed toxin of Bacillus and viable Citrobacter organisms has been associated with food poisoning and other non-gastrointestinal infections in human beings ${ }^{48-52}$. For instance, toxin produced by these organisms is known to cause diseases of the gastrointestinal tract ${ }^{48-52}$. Diarrhoea is one of the leading causes of morbidity and mortality in Malawi $i^{6,7,46}$, probably intake of herbal medicines could be an important risk factor in this population. It is an undeniable fact that in Malawi herbal

Figure 3. Level of bacterial contamination in different herbal medicinal formulations.

contaminants with a mean range of 1400 to 1792.86 CFU/ $\mathrm{ml}$ in Mibawa and Limbe samples respectively. Tablet formulated samples had the least number of detected bacterial contaminants which ranged from 400 to $750 \mathrm{CFU} /$ $\mathrm{ml}$ in Lunzu and Mibawa samples respectively. Interestingly, it was noted that there were no statistical mean differences in the levels of bacteria among the three markets.

\section{Heavy metal contamination}

Heavy metal contamination was observed in medicinal herbs (Table 2). Of all the 4 heavy metals analysed, lead was the most contaminating metal with mean value of $0.091 \pm 0.107$ medicine is consumed as supplements and drugs, although we were unable to find published evidence to support this view.

On the contrary, the present study has lower bacterial count than the studies conducted elsewhere, 10, 53, 54. These differences could be as a result of variation in geographical area and physicochemical properties associated with herbal medicine which influence microbial distribution and their number ${ }^{54}$. Interestingly, Bacillus spp. was reported as the most contaminating organism by others ${ }^{55}$. Furthermore, some studies have reported the presence of Salmonella typhi, Shigella spp. and Eschericbia coli unlike in the present study ${ }^{56}$. Absence of these microbes in the present study may mean that herbal 
medicines in Blantyre are not that highly contaminated because WHO demands the limit of these to be nil. More can be done to educate the traditional healers.

Although the majority of the samples recorded total count beyond the WHO recommended levels the results herein were highly variable among the samples. The relatively low levels of bacterial contamination encountered in tablets samples were due to the absence or low levels of moisture content since the tablets were highly dried as indicated by the vendors. This indicates that herbs prepared as tablets are arguably safer and yields acceptable bacterial levels. Similarly, drying of powdered samples reduced the moisture content of the samples which is one of the microbial growth requirement ${ }^{57}$. However, the levels on average are not acceptable as they are beyond WHO regulatory limits. High levels of bacterial count in some samples especially in liquid samples may have resulted from the use of contaminated water or the samples coming in contact with contaminated soil prior to their preparation. The researchers noted that, herbal preparations were made in an open environment making it more likely to get contaminated as opposed to close compartment. It was also observed that clean water was scarce in these sampled markets, majority using unsafe unpiped water means (i.e. rivers, untidy basins, rainy water from iron sheets etc.). It is obvious to conclude that these levels of contamination can be shared with our neighbouring countries, hence most of these herbs are sourced from Mulanje Mountain which borders Malawi and Mozambique while other vendors indicated that their herbs are obtained from Mozambique and Tanzania. It is therefore recommended that training vendors would be vital in prevention of bacterial contamination of herbal products. Besides this policies and regulations concerning herbal safety must be acknowledged and implemented by authorities.

The heavy metal levels found in the present study are comparable to existing studies in other parts of the universe $\mathrm{e}^{24}, 58,59$. However, the levels reported herein exceed Canadian regulatory limits for $67 \%$ of lead and $11 \%$ for Cadmium. This could be due to variation in soil and geoclimatic characteristics, growing site, species or genotype and agrotechniques which affect heavy metal content in medicinal and aromatic plants ${ }^{60-64}$. It is also tempting to speculate that the herbal medicine sold in Blantyre do not contain deliberate added heavy metals, hence the levels of lead and Cadmium were marginal while Mercury and Arsenic were undetectable. The levels were evenly distributed among the sampled markets. The presence of lead and cadmium in herbal products could be linked to the fact that the medicinal plants obtained these elements from the soil during growth via roots which remained in the plant tissues after processing or unhygienic post processing storage condition ${ }^{24,26,27}$.

Heavy metals must be regularly monitored because from this study lead and cadmium were found at high concentrations. This could be due to widespread use of organic manures, synthetic fertilizers, lime, which could contaminate herbal plants through water sources. Increased use of lead and cadmium in industrial products such as batteries, paints and other electronic products which are unhygienically disposed of to pollute the environment is a major culprit ${ }^{26,27}$. The presence of heavy metal content exceeding the Canadian regulatory levels herein have a greater health implication as cumulative toxic impact can have negative effects ${ }^{41}$. Additionally, individuals would get heavy metals from food and ground water which can increase bioavailability of these elements in the body. It is therefore, proposed that some studies must be conducted to assess bioavailability of heavy metals among individuals using herbal medicine and also content of heavy metals in food Products. It is highly recommended that these metals must be monitored and vendors must be trained in good agronometric and processing practices. Since heavy metals are associated with soils where herbal medicines were grown, further study to determine geographical location where herbal medicines are coming from in Malawi would give a clue as to which region or location is showing pattern of heavy metals and advice can be given accordingly to the herbalists.

Heavy metals are not easily noticed by consumers and their cumulative effect may lead to serious adverse health issues. As such consumers must be protected and interventions are needed to enforce the policies and regulations. Similar metals were detected in herbal products elsewhere ${ }^{24,58}$ and the authors concluded that it is an indication of global emergency and countries must step up with safety measures before tremendous disabilities are registered by consumers.

\section{Conclusion}

The levels of bacterial contamination are of concern, and therefore regulatory measures need to be enforced to reduce bacterial contamination levels to the WHO regulatory limits. The common organisms detected are coliforms such as Citrobacter, Enterobacter, Klebsiella, other-coliforms and gram positive aerobic Bacillus and coagulase negative Staphylococcus species. Occurrence of the majority of these organisms exceeded WHO regulatory limits. The herbal medicinal samples contamination with lead exceeded the Canadian regulatory limits while arsenic and mercury were within regulatory limits. This should serve as a wake-up call for action for national regulatory authorities. Such action should involve instituting of national regulations and guidelines on use of herbal medicine and set limits for natural contaminants. It is highly recommended that societies and the decision makers need to be educated about bacterial and heavy metal contamination of herbal medicine.

\section{Consent for publication}

This is not applicable because there is no any individual person's data involved informs of personal details, images or videos.

\section{Competing interests}

The authors declare that they have no competing interests. Authors' contributions

MHK, OP conceived and designed the experiments. MHK, OP, TM performed the experiments. MHK, OP analysed data. MHK, OP, TM contributed reagents and analysis tools. MHK, MCL, JM, BLZ, TL, OP, TM, JK wrote the paper. All authors provided revisions and approved the manuscript. Author details

${ }^{1}$ Malawi Adventist University, Malamulo College of Health Sciences Campus, Biomedical Science Department, Microbiology Research Group. ${ }^{2}$ University of Malawi, Chancellor College, Zomba, Malawi. ${ }^{3}$ Faculty of Pharmacy, University of Ibadan, Nigeria. Africa Centre of Excellence in Public Health and Herbal Medicine, University of Malawi. Department of Pharmacy, College of Medicine, University of Malawi, Malawi. ${ }^{4}$ Malawi University of Science and Technology, Malawi. ${ }^{5}$ University of Malawi, College of Medicine. 
MK; kalumbim@mchs.adventist.org or kalumbim"mchs. adventist.org, MCL; martinclikongwe@yahoo.com or mlikongwe@cc.ac.mw, JP; jmponda@medcol.mw , BLZ; bahatzimba@gmail.com or bahat.zimba@yahoo.com, TL; tlipenga@medcol.mw or trancizeo@outlook.com, OP; odalaphiri@gmail.com, TM; tmguntha@cc.ac.mw,

JK; jkumphanda@gmail.com.

\section{Acknowledgement}

We are grateful to all the vendors and herbal clinics owners who provided useful information and the samples. We would like to thank Malamulo Mission Hospital and College of Health Sciences Microbiology Laboratory and Chancellor College Chemistry Laboratory staff for their immense contribution in the analysis and interpretation of the tests.

\section{Funding}

This work was not supported by any grant.

\section{Availability of data and materials}

Upon request all the data will be shared. All the datasets are well stored by the corresponding author.

\section{Ethics approval and consent to participate}

Although the study did not directly involve the human beings, ethics approval was sought from National Health Science Research Committee (Approval number; 2298).

\section{References}

1. World Health Organization. WHO global report on traditional and complementary medicine 2019. Geneva. World Health Organization; 2019.

2. Welz AN, Emberger-Klein A, Menrad K. Why people use herbal medicine: insights from a focus-group study in Germany. BMC Complement Med Ther. 2018; 18:92.

3. Oyebode O, Kandala NB, Chilton PJ, Lilford RJ. Use of traditional medicine in middle-income countries: a WHO-SAGE study, Health Policy and Planning. 2016; 31, Issue 8, October 2016, Pages 984-991.

4. Kneifel W, Czech E, Kopp B. Microbial Contamination of Medicinal Plants -A Review. Planta Med. 2002; 68(1): 5-15.

5. World Health Organization. Disease burden and mortality estimates [website]. WHO-MCEE estimates for child causes of death 2000-2016. Geneva: World Health Organization; 2018.

6. Institute for Health Metrics and Evaluation. The Global Burden of Disease Study 2010. 2301 Fifth Ave., Suite 600 Seattle, WA 98121 USA; 2018.

7. National Statistical Office (NSO) [Malawi] and ICF. Malawi Demographic and Health Survey 2015-16. Zomba, Malawi, and Rockville, Maryland, USA; 2017.

8. World Health Organization. Global Health Estimates 2016: Deaths by Cause, Age, Sex, by Country and by Region, 2000-2016. Geneva, World Health Organization; 2018.

9. Martins HM, Martins ML, Dias MI, Bernardo F. Evaluation of microbiological quality of medicinal plants used in natural infusions. Int J Food Microbiol. 2001; 68: 149-153.

10. Rangsipanuratn W, Kammarnjassadakul P, Janwithayanuchit I, Paungmoung P, Ngamurulert S, Sriprapun M, et al. Detection of microbes, aflatoxin and toxic heavy metals in Chinese medicinal herbs commonly consumed in Thailand. Pharm Sci Asia. 2017; 44 (3): $162-$ 171.

11. Van Vuuren S, Williams VL, Sooka A, Burger A, Van der Haar L. Microbial contamination of traditional medicinal plants sold at the Faraday muthi market, Johannesburg, South Africa. S. Afr. J. Bot. 2014; 94: $95-100$.
12. Farkas J. Spices and herbs in: The microbiological safety and quality of food, aspen publishers Gaithersburg. 2000; 897-918.

13. Candlish AAG, Pearson SM, Aidoo K, Smith JE, Kelly B, Irvine H. A survey of ethnic foods for microbial quality and aflatoxin content. Food Addit Contam. 2001; 18(2):129-36.

14. Temu MJ, Lyamuya EF, Makwaya CK. Sources of Microbial Contamination of Local Herbal Medicines Sold on the Open Market in Dar es Salaam, Tanzania. East and Central African Journal of Pharmaceutical Sciences. 2009; 12: 19-22.

15. Walther C, Marwa KJ, Seni J, Hamis P, Silago V, Mshana SE, et al. Microbial contamination of traditional liquid herbal medicinal products marketed in Mwanza city: magnitude and risk factors. Pan Afr Med J. 2016; 23:65.

16. Borwn JC, Jiang X. Prevalence of antibiotic-resistant bacterial on herbal products. J Good Prot. 2008; 71:1486-90.

17. Tiwari R, Tiwari G. Use of antibiotics: from proceeding to contemporary. Scholars' Res J. 2011; 1:59-68.

18. Kalumbi M. Effect of processing method and concentration of Mangifera indica leaf extract on their antibacterial activity against Staphylococcus aureus. Int J Herb Med. 2018; 6(6): 116-119.

19. Kalumbi M. Effect of Vancomycin, tetracycline, Persia americana leaf extract and combinations thereof on antibacterial activity against pathogenic organisms. J Pharmacogn Phytochem. 2019; 8(1): 27332737.

20. Makoka MH, Miller WC, Hoffman IF, Cholera R, Gilligan PH. Kamwendo D, et al. Bacterial infections in Lilongwe, Malawi: aetiology and antibiotic resistance. BMC Infect Dis. 2012; 12:67.

21. Musicha P, Cornick JE, Bar-Zeev N, French N, Masesa C, Denis $\mathrm{B}$, et al. Trends in antimicrobial resistance in bloodstream infection isolates at a large urban hospital in Malawi (1998-2016): a surveillance study. Lancet Infect Dis. 2017; 17: 1042-52.

22. Grant DS. Seafood Health Facts: Making Smart Choices. Balancing the Benefits and Risks of Seafood Consumption. Resources for Healthcare Providers and Consumers. National Oceanic and Atmospheric Association; U.S. Department of Commerce and the National Integrated Food Safety Initiative; National Institute of Food and Agriculture; U.S. Department of Agriculture; 2016.

23. World Health Organization. WHO guidelines for assessing quality of herbal medicines with reference to contaminants and residue. Geneva: WHO; 2007.

24 Glavac NK, Djogo S, Razic S, Kreft S, Veber M. Accumulation of heavy metals from soil in medicinal plants. Arh Hig Rada Toksikol. 2017; 68:236-244.

25. Raghavan S. Handbook of spices, seasonings, and flavorings. 2nd ed Boca Raton, FL: CRC Press; 2007; Spices in history 1-9.

26. Annan K, Kojo AI, Cindy A, Samuel A, Tunkumgnen BM. Profile of heavy metals in some medicinal plants from Ghana commonly used as components of herbal formulations. Pharmacognosy Res. 2010; 2(1):41- 4 .

27. WHO/FAO guidelines for assessing quality of herbal medicines with reference to contaminants and residues; 2007. http://apps.who.int/ medicinedocs/documents/s14878e/ s14878e.pdf.

28. Annan K, Dickson RA, Amponsah IK, Nooni IK. The heavy metal contents of some selected medicinal plants sampled from different geographical locations. Pharmacognosy Res. 2013; 5(2): 103-108.

29. Cataldo DA, Wildung RE. Soil and Plant Factors Influencing the Accumulation of Heavy Metals by Plants. Environ Health Perspect. 1978; 27: 149-159.

30. Gogtay NJ, Bhatt HA, Dalvi SS, Kshirsagar NA. The use and safety of non-allopathic Indian medicines. Drug Saf. 2002; 25(14):1005-19.

31. Ernst E. Adulteration of Chinese herbal medicines with synthetic 
drugs: a systematic review. J. Intern. Med. 2002; 252: 107-113.

32. Ko RJ. Adulterants in Asian Patent Medicines. N Engl J Med. 1998; $339: 847$

33. Kamath S, Pemiah B, Sekar R, Krishnaswamy S, Sethuraman S, Krishnan U. Mercury-based traditional herbo-metallic preparations: a toxicological perspective. Arch Clin Toxicol. 2012; 1-8.

34. Kumar SC, Moorthi C, Prabhu PC, Jonson BB, Venkatnarayan R. Standardization of anti-arthritic herbo-mineral preparation. Res J Pharm Biol Chem Sci. 2011; 2:679-684.

35. World Health Organization Geneva. WHO guidelines on good agricultural and collection practices (GACP) for medicinal plants. Geneva: WHO; 2003.

36. European Medicines Agency. Evaluation of Medicines for Human Use. 7 Westferry Circus, Canary Wharf, London, E14 4HB, UK; 2006.

37. Jarup L. Hazards of heavy metal contamination. Br. Med. Bull. 2003; 68(1):167-182.

38. Martin S, Griswold W. Human health effects of heavy metals. Environmental Science and Technology Briefs for Citizens. 2009; 15:16.

39. Bernard A. Cadmium \& its adverse effects on human health. Indian J Med Res. 2008; 128(4):557-564.

40. Valko M, Morris H, MTD C. Metals, toxicity and oxidative stress. Curr Med Chem. 2005; 12:1161-1208.

41. Martinez VD, Vucic EA, BeckerSantos DD, Gil L, Lam WL. Arsenic exposure and the induction of human cancers. J. Toxicol.. 2011; 2011:113

42 Kasilo OM, Trapsida JM. Regulation of tradition medicine in the WHO African region . Afr Health Mon, 2010; 25-31.

43 WHO. Traditional medicine fact sheet. No 134. 2015.

44. National Committee for Clinical Laboratory Standards NCCLS. Methods for dilution antimicrobial susceptibility tests for bacteria that grow aerobically: Approved standards- fifth edition. NCCLS document M7-A5. NCCLS: Wayne, PA, USA, 2000.

45. Obi E, Dora N. Akunyili B, Ekpo OE, Orisakwe. Heavy metal hazards of Nigerian herbal remedies. Sci Total Environ.2006; 1 (369):35-41

46. Bowie C. (2006). The burden of disease in Malawi. Malawi Med J; 18 (3): 103-110.

47 Ray B, Bhunia A. Fundamentals of Food Microbiology $4^{\text {th }}$ ed. CRC Press, New York. 2008. Pp 21

48 Bai L, Xia S, Lan R, Liu L, Ye C, Wang Y, et al. Isolation and characterization of cytotoxic, aggregative Citrobacter frundii. Plos ONE 7 (3); e33054,

49 Dronbniewsk FA. Bacillus cereus and related soecies. Clin. Microbiol. Rev. 1993; 6: 324-33338.

50 Granum PE, Lund T. Bacillus cereus and its food poisoning toxins FEMS Microbiol. Lett. 157: 223-228.
51 Kotiranta AK, Lounatmaa, Hapasalo. Epidemiology and pathogenesis of Bacillus cereus infections. Microbes infec. 2000: 189-198.

52 Phelps RJ, Mckillip JL. Enterotoxin production in natural isolates of Bacilleae outside Bacillus cereus group. Appl. Environ. Microbiol. 2002: 6; 3147-3151.

53. Yesuf A, Wondimeneh Y, Gebrecherkos T, Moges F. Occurrence of potential bacterial pathogens and their antimicrobial susceptibility patterns isolated from herbal medicinal products sold in different markets of Gondar town, Northwest Ethiopia. Int J Bacteriol. 2016; 2016, 11 pages.

54. Zhao XY, Wei Z, Zhao Y, Xi B, Wang X, Zhao $T$, et al. Environmental factors influencing the distribution of ammonifying and denitrifying bacteria and water qualities in 10 lakes and reservoirs of the Northeast, China. Microb Biotechnol. 2015; 8(3): 541-548.

55. Vitullo M, Ripabell G, Fanelli I, Tamburro M, Delfine S, Sammarco ML. Microbiological and toxicological quality of dried herbs. Lett Appl Microbiol. 2011a; 52:573-580.

56. Abba D, Inabo HI, Yakubu SE, Olonitola OS. Contamination of herbal medicinal products marketed in Kaduna Metropolis with selected pathogenic bacteria. Afr J Tradit Complement Altern Med. 2009; 6:7077 .

57 Peleg M, Gorradini MG, Normand MD. On modelling the effect of water activity on microbial growth and mortality kinetics. In GutierrezLopez G, Alamilla-Beltran L. Del Pilar Buera M,Welti Chanes J, Parada-Arias E, Barbosa-Canovas G. (eds) Water stress in Biological, Chemical, Pharmaceutical and Food Sytems, Food Engineering Series. Springer, New York, NY. 2015.

58. Qing-hua Y, li Y, Qing W, Xiao-qin M. Determination of major and trace elements in six herbal drugs for relieving heat and toxic by ICPAES with microwave digestion. J Saudi Chem Soc. 2012; 16: 287-290.

59. Alwakeel SS. Microbial and heavy metal contamination in of herbal medicines. Res J Microbiol. 2008; 3 (12): 683- 691.

60. Adriano DC. Trace Elements in Terrestrial Environments: Biogeochemistry, Bioavailability and Risks of Metals (2nd Ed), Springer, New York. 2001: pp 867.

61. Chizzola R, Michitsch H, Franz C. Monitoring of metalic micronutriens and heavy metals in herbs, spices and medicinal plants from Austria. Eur Food Res Technol. 2003; 216:407 - 411.

62. Yoon J, Cao X, Zhou Q, Ma LQ. Accumulation of $\mathrm{Pb}, \mathrm{Cu}$, and $\mathrm{Zn}$ in native plants growing on a contaminated Florida site. Sci Total Environ. 2006: 368: 456-464.

63. Radanovic D, Antic-Mladenovic S, Jakovljevic S, Maksimovic S. Content of $\mathrm{Pb}, \mathrm{Ni}, \mathrm{Cr}, \mathrm{Cd}$ and $\mathrm{Co}$ in Peppermint (Mentha piperita L.) cultivated on different soil types from Serbia. Rostlinna Vyroba. 2001; 47:111-116.

64. FAO/WHO. Joint FAO/WHO food standards programme; The report of the 10th session of the codex committee on contaminants in foods (rep16/cf); Codex Alimentarius Commission. Viale delle Terme di Caracalla, 00153 Rome, Italy. 2016. 